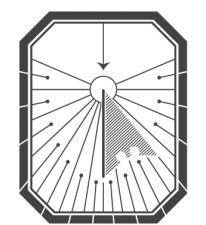

KYIV-MOHYLA

LAW \& POLITICS JOURNAL

KYIV-MOHYLA SCHOLARLY PEER-REVIEWED JOURNALS

Legal Accountability for the Holodomor-Genocide of 1932-1933 (Great Famine) in Ukraine

Author: Myroslava Antonovych

Source: Kyiv-Mohyla Law and Politics Journal 1 (2015): 159-176

Published by: National University of Kyiv-Mohyla Academy

http://kmlpj.ukma.edu.ua/ 


\title{
Legal Accountability for the Holodomor-Genocide of 1932-1933 (Great Famine) in Ukraine
}

\author{
Myroslava Antonovych \\ National University of Kyiv-Mohyla Academy, \\ Department of International Law
}

\begin{abstract}
This article deals with the problem of legal accountability for the 1932-1933 Holodomor in Ukraine under international and regional legal instruments, international customary law and Ukrainian legislation. The article focuses on Ukraine's obligation to punish persons for the grave human rights violations of the communist regime then in power in accordance with the 1948 Convention on the Prevention and Punishment of the Crime of Genocide (Genocide Convention) and Council of Europe Resolutions 1096 (1996) and 1481 (2006). The author concludes that holding the Communist Party of Ukraine responsible for the Holodomor will help Ukrainians to cope with their totalitarian communist past.
\end{abstract}

Key Words: the Holodomor of 1932-1933, genocide, Convention on the Prevention and Punishment of the Crime of Genocide, legal accountability for genocide.

\section{Introduction}

The question of the legal accountability for the crime of the Holodomor of 1932-1933 in Ukraine is linked to how this crime is classified. If the Holodomor is genocide, ${ }^{1}$ Ukraine has a duty to punish the perpetrators under Article 1 of the Genocide Convention. In relevant part, Article 1 states that "[t]he Contracting Parties confirm that genocide, whether committed in time of peace or in time of war, is a crime under international law which they undertake to prevent and to punish."

In addition, the UN Convention on the Non-Applicability of Statutory Limitations to War Crimes and Crimes against Humanity states that "[n]o statutory limitation shall apply to the following crimes, irrespective of the date of their commission: [...] (b) Crimes against humanity whether committed in time of war or in time of peace [...] and the crime of genocide as defined in the 1948 Convention on the Prevention and Punishment of the Crime of Genocide, even if such acts do not constitute a violation of the domestic law of the country in which they were committed" (Article $1 \mathrm{~b}$ ). Moreover, the prohibition of genocide is a jus cogens norm of international customary law, which has retroactive force.

1 In Ukraine the Holodomor was recognized as genocide by 2006 Law "On Holodomor in Ukraine of 1932-1933" and by the 2010 Ruling of Kyiv Court of Appeal. 
I argue that the Holodomor constitutes the crime of genocide for which the Genocide Convention and international customary law demand punishment. The persons who committed the crime will forever escape punishment because they are dead. Therefore, as it is obligated to do under international and European law, Ukraine should punish the entity that conceived and carried out the genocide - the Communist Party of Ukraine, a former branch of the now defunct Communist Party of the Soviet Union (the USSR).

Position of the Council of Europe regarding former totalitarian communist regimes changed from recommending, in 1996, ${ }^{2}$ that they dismantle their totalitarian communist heritage to, in $2006^{3}$ in Resolution 1481, condemning their communist-era crimes. The Parliamentary Assembly of the Council of Europe (PACE) intended for Resolution 1481 to be practically significant, for it stressed that "totalitarian communist regimes are still active in some countries of the world and crimes continue to be committed." Furthermore, PACE called on all communist or postcommunist parties among its member states that have not yet done so to reassess the history of communism and their own past, to clearly distance themselves from the crimes committed by totalitarian communist regimes, and to condemn these crimes unambiguously.

Referencing Resolution 1481, PACE adopted Resolution 1723 (2010) on Commemorating the victims of the Great Famine [Holodomor] in the former USSR in which it stressed that mass starvation was caused by the cruel and deliberate actions and policies of the Soviet regime. It strongly condemned the cruel policies pursued by the Stalinist regime, which resulted in the death of millions of innocent people, as a crime against humanity. PACE resolutely rejected any attempts to justify those deadly policies for whatever purposes and recalled that the right to life is non-derogable.

The Communist Party of Ukraine has yet to comply with these requirements, and thus the issue of legal accountability for the Holodomor-genocide against Ukrainians as well as for other crimes against humanity remains open. Recently Ukraine's Ministry of Justice has sued the Communist Party of Ukraine in the Kyiv District Administrative Court for its support of terrorists in the Eastern Ukraine in April-June 2014 and for other crimes against humanity. In July 2014, the faction of the Communist Party was dissolved in the Verkhovna Rada of Ukraine.

\section{Legal Sources of the Holodomor as Genocide}

Under Article 2 of the Genocide Convention, the crucial element to establish genocide is evidence of acts taken with the specific intent to destroy, in whole or in part, a national, ethnical, racial or religious group as such. Although archived legal documents reveal the Holodomor

The Council of Europe Resolution 1096 (1996) on Measures to dismantle the heritage of former communist totalitarian systems: Text adopted by the Parliamentary Assembly of the Council of Europe on June 27, 1996 (13th Sitting), accessed February 13, 2014, http://assembly.coe.int/Main.asp?link=/Documents/AdoptedText/tag6/ERES1og6.htm.

3 The Council of Europe Resolution 1481 (2006) on Need for international condemnation of crimes of totalitarian communist regimes: Text adopted by the Parliamentary Assembly of the Council of Europe on January 25, 2006 (5th Sitting), accessed April 2, 2013, http://assembly.coe.int/Mainf.asp?link=/Documents/AdoptedText/tao6/Eres1481.htm. 
in Ukraine as genocide against Ukrainians, some argue that not a single decree of the Soviet government and the Central Committee of the Communist Party containing an order to kill with famine a certain number of Ukrainian or other peasants has been found by researchers. ${ }^{4}$ Viktor Kondrashyn and Diana Penner state in their book Famine of 1932-1933 in a Soviet Village: On the Materials of Volga region, Don and Kuban that evidence that the famine of 1932-1933 was thoroughly planned has not yet been established. However, it would be naïve to think that such a criminal power as the USSR would explicitly issue decrees to kill millions of Ukrainian peasants. Instead, that intent is implicitly expressed in many legal acts of Soviet authorities. In addition, numerous legal documents of international and foreign bodies recognize that the case of the 1932-1933 Holodomor in Ukraine was an act of genocide against Ukrainians. Famous scholars further bring the case forward in a wide array of historical documents, memoirs and writings.

\section{Legal Documents of Ukrainian SSR and the USSR}

Foremost among the legal sources are laws and by-laws adopted by the Central Executive Committee (CVK) and the Council of People Commissars (RNK) of the USSR and Ukrainian SSR. On 25 October 1932, under the leadership of S. V. Kosior, the Politburo of the Central Committee $(\mathrm{CK})$ of the Communist Party of bolsheviks of Ukraine $(\mathrm{CP}(\mathrm{b}) \mathrm{U})$ adopted the resolution "On the Necessity to Overcome Ukraine's Lagging behind in Fulfilling the Grain Procurement Plan," which increased the tempo of the annual grain procurement plan ten times. On 30 October 1932, the Politburo of the $\mathrm{CK}$ of the $\mathrm{CP}(\mathrm{b}) \mathrm{U}$ adopted the resolution "On Measures to Intensify Grain Procurement," which demanded that local authorities prevent the sale of grain or industrial goods in Ukraine and strengthen judicial repressions. The intent was clear to destroy peasant owners who were mostly Ukrainians.

Another resolution, issued on 14 December $193^{2,5}$ of the CK of All-Union Communist Party of Bolsheviks (VCP(b)) and RNK of the USSR entitled "On Grain-collection in Ukraine, the Northern Caucasus and in the Western Region" demonstrates that the government was scared of the results of Ukrainization. By implementing this policy beyond the "allowed margins," grain storage was to become a method of suppressing social and national resistance. This resolution, therefore, clearly and directly connects grain storage policies to the results of Ukrainization.

To eliminate resistance to grain storage by kulak elements and their party and non-party menials [prysluzhnykiv], the CK and RNK of the USSR approved various actions, including that the $\mathrm{CK}$ of $\mathrm{CP}(\mathrm{b}) \mathrm{U}$ and RNKU attend to carrying out of Ukrainization correctly. This meant eliminating the machinery of Ukrainization, turning out the Petliura and other bourgeois and nationalistic elements from party and Soviet bodies, thoroughly choosing and bringing up

4 V. Kondrashin and D. Penner, Golod: 1932-1933 gody v sovietskoi derevnie (na materialakh Povolzhia, Dona i Kubani) [Famine of 1932-1933 in a Soviet Village: On the materials of Volga Region, Don and Kuban] (Samara-Penza, 2002), 23. 
Ukrainian bolshevik cadres, and guaranteeing systematic party leadership and control over the implementation of Ukrainization.

Kosior and Chubar obtained a right to suspend the supply of goods to Ukrainian villages until they fulfilled their grain storage plan. Yet, because those plans of grain storage were exaggerated, suspending the supply of goods to Ukrainian villages meant a famine in those villages. This right applied only to Ukrainian villages.

The system of "black plaques" (blacklists) was also established in the Ukrainian regions of Kuban (by resolution of 4 November 1932) and in the rest of Ukraine by resolution of 18 November 1932. Villages placed on "black plaques" were surrounded by military troops, all their goods and seeds stores were seized, and the trade in and the procurement of any goods was forbidden. Therefore, in practice, a village placed on a "black plaques" saw its peasants starve to death. As early as 6 December 1932, a joint Decree of CK CP(b)U and RNKU announced that 6 Ukrainian villages were placed on "black plaques." Subsequently, new collective farms were added to the list of "black plaques." For example, by the decision of Dnipropetrovsk regional committee of $\mathrm{CP}(\mathrm{b}) \mathrm{U}$ on 23 December 1932, 22 farms were placed on the list. In total, collective farms in 82 regions of Ukraine, amounting to a quarter of administrative districts, with a population of 5 million people were placed on the "black plaques." 6

In addition to an unrealistic plan for state grain collection and punishment for failure to fulfil the quotas established by the USSR, peasants were deprived of the right to leave Ukraine. A decision of the Politburo on 15 November 1932 excluded issuing passports to peasants. Moreover, in January 1933, Stalin's order banned peasants from leaving the territory of Ukrainian SSR and Kuban to get bread in other territories of the USSR. ${ }^{7}$

Other documents testify to the genocide in Ukraine. For example, the German Government Report on Vinnytsia $1944^{8}$ documented "illegal acts of the government of the USSR, most notably at Vinnytsia and during the engineered terror-famine of 1932-1933."

Far from being complete, the acts of the Ukrainian SSR and the USSR I have summarized here establish well-planned genocide perpetrated against the Ukrainian people.

6 My zvynuvachuiemo! Holodomor 1932-1933 rokiv — henotsyd ukrainskoho narodu [We Accuse! The 1932-1933 Holodomor as a Genocide of the Ukrainian People] (Kyiv: Ukrainskyi instytut natsionalnoi pamiati, 2007), 39.

7 Rishennia Politburo CK VKP(b)"Pro pasportnu systemu ta rozvantazhennia mist vid zaivykh elementiv," [Decision of the Politburo of CK VKP(b) "On Passport System and Releasing of Cities from Redundant Elements,"] November 15, 1932; Direktiva CK VKP(b) i Sovnarkoma SSSR "O nedopushchenii massovogo vyiezda krestian," [Order of CK VKP(b) and Sovnarkom of SSSR “On Banning of Mass Leaving of Peasants,”] of January 22, 1933 in My zvynuvachuyemo! 42.

8 “German Government Report on Vinnytsia 1944," in The Tragedy of Vinnytsia Materials on Stalin's Policy of Extermination in Ukraine during the Great Purge, 1936-1938, ed. Ihor Kamenetsky (Toronto; New York: Ukrainian Historical Accosiation, 1989), 91, 168-210.

9 Richard C. O. Rezie, "The Ukrainian Constitution: Interpretation of the Citizens' Rights Provisions," Case Western Reserve Journal of Intenational Law 31 (1999): 176. 


\section{Actions Taken by the Ukrainian People's Republic in Exile}

In response to the manmade famine of $193^{2-1933}$ in Ukraine, Ukrainians in Halychyna and neighboring territories protested widely, as is partially revealed in letters from the Government of the Ukrainian People's Republic (UPR) in exile and from various organizations and parties. There were letters of the Government of the UPR in exile to foreign trade agencies of European states requesting them to halt the bread trade with the USSR. In addition, a government representative, Oleksandr Shulhyn, wrote on 25 September 1933 to the Head of the Council of the League of Nations, Mr. Mowinkel, asking him to raise the painful question of the famine in Ukraine as "the very existence of a great nation was being threatened." ${ }^{10}$ In another letter addressed to the head of the 14th Assembly of the League of Nations, Mr. Voter, the League of Nations was asked to take all necessary measures to prevent the exportation of bread from the USSR, actually from Ukraine, to organize a commission for determining the real extent of the tragedy and to organize international aid for the starving people.11

In 1983, the Government-in-exile of the Sovereign Ukraine (1917-1920) presented an Accusation Act against the Government of the USSR regarding the Great Famine of 1932-1933 to the International Court of Justice in The Hague. The Court did not accept the petition on the grounds that Ukraine did not then exist as an independent state. Now that Ukraine has achieved independence, the case of the Great Famine is waiting to be pleaded.

\section{Legal Sources of Independent Ukraine}

The Ukrainian genocide was recognized by the Ukrainian Law "On the Holodomor in Ukraine of 1932-1933" of 28 November 20o6..$^{12}$ Article 1 of this law states that "The Holodomor of 1932-1933 in Ukraine was genocide against the Ukrainian people." Under Article 2 of this law, public denial of the Holodomor is illegal.

Following a request from the World Congress of Ukrainians, the National Commission for Strenthening Democracy and the Rule of Law approved a Conclusion on 16 May 2008 that the Holodomor of 1932-1933 in Ukraine was an act of genocide against the Ukrainian people. This

10 See: V. Marochko, "Dyplomatiia zamovchuvannia: Stavlennia zakhidno-ievropeiskykh derzhav do Holodomoru 1932-1933 rr. v Ukrayini," ["The Failure to Mention Diplomacy: Attitude of the Western European States towards the Holodomor of 1932-1933 in Ukraine,"] in Holod-henotsyd 1933 roku v Ukraini: Istoryko-politolohichnyi analiz sotsialno-demohrafichnykh ta moralno-psykholohichnykh naslidkiv, paper presented at the international scientific and theoretical conference, November 28, 1998 (Kyiv; New-York: M. P. Kots Publisher, 1998), 151-52.

11 Marochko, “Dyplomatiia zamovchuvannia," 154; James Mace, “The Voices of Suffering," Ukrainian World 3-12 (1993): 34, 36.

12 Law of Ukraine "On the Holodomor in Ukraine of 1932-1933," of November 28, 2006, accessed May 14, 2013, http://canada.mfa.gov.ua/en/ukraine-\%Dı\%81\%Do\%Bo/holodomor-remembrance/ holodomor-remembrance-ukraine/holodomor-law-ukraine. 
conclusion used the definition of genocide found in the Genocide Convention. ${ }^{13}$ Point 6 of the Conclusion added that the recognition of the Holodomor of 1932-1933 in Ukraine as a genocide against the Ukrainian people corresponds to the purpose of the Genocide Convention. This Convention's principal aim is to ensure that genocide is punished.

Finally, on 13 January 2010, the Kyiv Court of Appeal adopted the Ruling [Postanova] in the criminal case opened by the Security Service of Ukraine that genocide was committed against Ukrainians in 1932-1933 ${ }^{14}$ (Article 442 of the Criminal Code of Ukraine). The pre-trial investigation proved irrefutably that in 1932-1933J. Stalin, V. Molotov, V. Kaganovich, P. Postyshev, S. Kosior, V. Chubar, and M. Khataievich organized and committed the crime of genocide in Ukraine by deliberately inflicting on the part of Ukrainian national group conditions of life calculated to bring about its physical destruction. The Court concluded that these persons acted against the very existence of the targeted Ukrainians. It confirmed that the living conditions imposed on them were meant to kill them and that 3,941,ooo were exterminated. It also was uncontrovertibly proven that the Holodomor was planned by those named and committed as one of the stages in a special operation against the Ukrainian national group as such. Only the Ukrainians, not other ethnic minorities, had sought to create a state and to achieve selfgovernance through an independent Ukraine as authorized the Constitution of the USSR. For this reason, the Ukrainian national group and its substantial component - the Ukrainian peasantry became the immediate target of the Holodomor of 1932-1933. Thus, the requisite direct criminal intent to commit genocide as set out in Article 442 of the Criminal Code of Ukraine was satisfied.

The Court, however, closed the criminal case because all the persons involved were dead. Nonetheless, the Chief Investigation Department of the Security Service of Ukraine found that those persons, intending to suppress the national liberation movement in Ukraine and to prevent the restoration and consolidation of an independent Ukrainian State, masterminded the genocide by creating conditions of life calculated to bring about destruction of the substantial part of the Ukrainian nation. In other words, they intentionally killed 3,491,0oo people through the Holodomor of 1932-1933 and thus committed the crime of genocide as defined in Article 442, Section 1 of the Criminal Code of Ukraine. ${ }^{15}$

13 Conclusion Regarding the juridical characterization of the Holodomor of 1932-1933 in Ukraine as the genocide of the Ukrainian people in relation to the definition formulated in the 1948 UN Convention on the Prevention and Punishment of the Crime of Genocide, adopted at the fourteenth plenary session of the Commission (Kyiv, May 16, 2008), accessed January 12, 2014, http://www.telusplanet.net/public/mozuz/holodomor/williams20o810o6FuteyOnyschuk.html. Ruling [Postanova] of the Kyiv Court of Appeal in the criminal case opened by the Security Service of Ukraine on the fact of committing genocide against Ukrainians in 1932-1933, adopted on 13 January 13, 2010 in The Holodomor of 1932-1933 in Ukraine as a Crime of Genocide under International Law, ed. Volodymyr Vasylenko, Myroslava Antonovych (Kyiv: Kyiv-Mohyla Academy Publisher, 2014), 294-356. 


\section{Actions Taken by Other Governments}

Among the documents of foreign states, one of the first to be adopted was Resolution 39a, submitted to the United States Congress by Congressman Hamilton Fish Jr. on 28 May 1934. This resolution enumerated the facts of the famine, recalled the American tradition of "taking cognizance" of such violations of human rights, expressed sympathy with the victims and signaled hope that the USSR would change its policies and allow for immediate American relief. It was referred to the Committee on Foreign Affairs and ordered to be printed (House Resolution 39a, 73rd Congress, 2nd Session).

In addition, foreign diplomats in the USSR sent letters and notes to their home governments expressing their views on the situation to their respective governments. The British Embassy, for example, reported to London that conditions in the Kuban and in Ukraine were "appalling" (British Embassy dispatch, March 5, 1933). German consuls in Kharkiv, Kyiv and Odesa, as well as the Italian consul in Kharkiv, Sergio Gradenigo, and others appropriately informed their governments about events in Ukraine. ${ }^{16}$

It was not until 1984 that the ninety-ninth United States Congress created the Commission on the Ukraine Famine to conduct a study of the 1932-1933 famine to expand the world's knowledge of the famine and provide the American public with a better understanding of the Soviet system by revealing the Soviet role in Ukraine's famine. ${ }^{17}$ Adopted by the Commission on 19 April 1988, the report was submitted to the Congress on 22 April 1988. It was preceded by two interim reports on meetings and hearings of the Commission of 1986 and $1987 \cdot{ }^{18}$ In its executive summary, the Commission formulated nineteen findings, one of which was that "Joseph Stalin and those around him committed genocide against Ukrainians in 1932-1933."19

From the 1990s to the beginning of the 21st century, when Ukraine started to research and to actively discuss issues of the Holodomor, the Australian, Argentinean, Georgian, Estonian, Italian, Canadian, Lithuanian, Polish, American, and Hungarian parliaments (as well as those of other countries) adopted resolutions or legislation condemning the Holodomor as genocide. For instance, the Australian Senate adopted a Resolution on 30 October 2002 that stated that the

16 Marochko, "Dyplomatiia zamovchuvannia," 147; Andrea Gratsiozi, ed., Lysty z Kharkova. Holodv Ukraini ta na Pivnichnomu Kavkazi v povidomlenniakh italiyskykh dyplomativ.1932-1933 roky [Letters from Kharkiv. Famine in Ukraine and in the Northern Caucasus in Notifications from Italian Diplomats of 1932-1933] (Kharkiv: Folio, 2007).

17 Investigation of the Ukraine Famine 1932-1933: Report to Congress Commission on the Ukraine Famine. Adopted by the Commission April 19, 1988. Submitted to Congress April 22, 1988 (Washington: United States Government Printing Office, 1988), v.

18 First Interim Report of Meetings and Hearings of and before the Commission on the Ukraine Famine Held in 1986 (Washington: Government printing Office, 1987); Second Interim Report of Meetings and Hearings of and before the Commission on the Ukraine Famine Held in 1987 (Washington: Government printing Office, 1988).

19 Investigation of the Ukraine Famine 1932-1933, vii. 
Holodomor was one of the genocides in the history of mankind. ${ }^{20}$ Seim of Lithuania adopted a Resolution on 24 November 2005 that stated that "Stalin's totalitarian regime committed a conscious and thoroughly planned genocide against the Ukrainian people." ${ }^{21}$ Likewise, the Georgian parliament recognized the Holodomor as genocide against the Ukrainian people committed by the totalitarian Bolshevik regime in $1932-1933 .{ }^{22}$ On 28 September 2010, the United States House of Representatives passed the Holodomor Resolution to solemnly remember the 75th anniversary of the Ukrainian famine-genocide of 1932-1933.

\section{Pronouncements of International Organizations}

There have been some attempts to organize "Nuremberg-style" tribunals for the crimes of the Communist Party of the Soviet Union (CPSU). Among the first steps in preparing for a trial of this sort was the creation of an International Commission of Inquiry into the 1932-1933 Famine in Ukraine. The Commission, initiated by the World Congress of Free Ukrainians, approached a number of jurists and legal scholars in different nations, asking them to participate in an inquiry into the famine that had taken place in Ukraine during 1932-1933. The Commission was formed on 14 February 1988 with seven commissioners: Colonel G. I. A. D. Draper, formerly a British prosecutor at the Nuremberg Trials; Prof. John P. Humphrey of Canada, formerly Director of the United Nations Division of Human Rights; Prof. G. Levasseur of France, formerly a member of the Commission for the Revision of the French Penal Code; Prof. R. Levene of Argentina, formerly the President of the Court of Appeals; Prof. C. T. Oliver, USA, former Assistant Secretary of State and US Ambassador; Prof. J. Sundberg of Sweden, appointed President of the Commission of Inquiry; and Prof. J. Verhoeven of Belgium, appointed Vice-President.

The Commission of Inquiry was established as an independent, non-governmental body. Under its Terms of Reference adopted on 14 February 1988, the Commission was to inquire and report on the existence and extent of the famine, its cause or causes and its effect on Ukraine. In addition, the Commission was charged with assessing responsibility for the famine through recommendations. ${ }^{23}$

In his opening statement, the counsel for the Petitioner (the World Congress of Free Ukrainians), Mr. John Sopinka, Q. C., submitted the contention that in 1932-1933 between five and ten million Ukrainians were starved to death as a result of a brutal enforcement of excessive grain-procurement quotas by the Soviet government. Mr. Sopinka asked the Commission to make the legal finding: (1) that the famine was deliberately caused as an instrument of state policy; (2) that the famine was an act of genocide; and (3) that Stalin, Molotov, Kaganovich, Postyshev and others were responsible. ${ }^{24}$

20

21

"Avstraliia vyznala Holodomor henotsydom," ["Australia has Recognized the Holodomor as Genocide,"] Za nashu Ukrayinu, July 7, 2003.

1 "Lytva vyznala holodomor v Ukraini henotsydom," ["Lithuania has Recognized the Holodomor in Ukraine as Genocide,"] Holos Ukrayiny, November 26, 2005, 6.

“Tse buv henotsyd," [“That was Genocide,"] Holos Ukrayiny, January 5, 2006, 1. International Commission of Inquiry into the 1932-1933 Famine in Ukraine, 1. International Commission, 2. 
As a result, it was established to the satisfaction of the Commission that it is beyond doubt that Ukraine was severely affected by the famine in 1932-1933 and that the Ukrainian and Soviet authorities were aware of the dire food shortages of the population. It was also indisputable that, although they were aware of the dramatic conditions in Ukraine, the Soviet authorities refrained from sending any relief until the summer of 1933. The Commission concluded that the Soviet authorities adopted various legal measures which amplified the disastrous effects of the famine by preventing the victims from finding any food at all or from leaving the region. It was confirmed that the Soviet authorities at the time denied the existence of any famine in Ukraine, and that, against all evidence to the contrary, they "persisted in their denials for more than fifty years, with the exception of Khruschev's private avowal."25

Although the International Commission of Inquiry into the 1932-1933 Famine in Ukraine was not a court, even less a criminal one, it, by its Terms of Reference, formulated recommendations regarding responsibility for the famine which "almost certainly lies with the authorities of the Soviet Union [...] Whatever the role of local authorities in the enforcement of particular policies, to the Commission majority it appears obvious that the prime responsibility rests with the central powers." 26

During the debates, and particularly in the closing submission by W. Liber, Esq. as counsel for the Petitioner, an accusation of genocide was made. ${ }^{27}$ The views of the members of the Commission differed. While Professors Verkhoeven, Humphrey and Levene deemed it plausible that the constituent elements of genocide existed at the time of the famine, Prof. Sundberg stated that his findings coincided with what was called genocide in the Genocide Convention, and Prof. Levasseur thought that a qualification of other facts found should establish it as a crime against humanity. Prof. Oliver was not convinced that the Petitioner had made a technical, legal case for genocide under the facts.

Based on the available documents, which did not include archived Soviet documents, a majority of the Commissioners did not believe that the $1932-1933$ faminehadbeen systematically organized to finally crush the Ukrainian nation..$^{28}$ Nonetheless, the Commission opined that the Soviet authorities used the famine to crown their new policy of denationalization. ${ }^{29}$

In its 58 th session, the UN General Assembly adopted a declaration signed by 64 states on the 7oth anniversary of the Holodomor, the "Great Famine in Ukraine in 1932-1933," that described the Famine as "a national tragedy for the Ukrainian people" that "took 7 to 10 millions of innocent lives." On 1 November 2007 at the 34th Session of the UNESCO General Conference 193 countries, unanimously passed a Resolution "On Remembrance of Victims of Holodomor in Ukraine" on the $75^{\text {th }}$ anniversary of the Holodomor. The Resolution expressed the conviction

25 International Commission, 45-48.

26 International Commission, $5^{-6 .}$

27 International Commission, 51. Mr. Liber became a counsel for the Petitioner when John Sopinka resigned after he was appointed to the Supreme Court of Canada. nation was too numerous to be crushed for all. The aim of Stalin's genocide was to destroy Ukrainian nation in part through starving to death its most numerous part - peasants. 
that the tragedy of Holodomor was caused by the harsh actions and politically totalitarian regime under Stalin and should be a warning to present and future generations to adhere to democratic values, human rights and legality. Ukraine offered a similar proposal at the 9th Session of the UN Human Rights Council. However, in view of the fact that other world forums were considering the issue of the Holodomor, the Ukrainian delegation on 22 September 2008, in a spirit of compromise, decided not to insist on a vote for the draft resolution by the Council..$^{30}$ Both the EU and the Council of Europe condemned the Holodomor as crime against humanity.

\section{Legal Doctrine}

International law considers among its sources the teachings of the most highly qualified publicists of various nations as a subsidiary means for determining rules of law. ${ }^{31}$ Many famous scholars consider the Holodomor of $193^{-1933}$ in Ukraine to be genocide. The author of the term "genocide," Rafael Lemkin, had no doubts that the Holodomor of 1932-1933 was a crime of genocide - "not simply a case of mass murder. It is a case of genocide, of destruction, not of individuals only, but of a culture and a nation." ${ }^{32}$ James Mace, Alan Besanson, Roman Serbyn and many other scholars consider the Holodomor to be a crime of genocide. ${ }^{33}$

Robert Conquest stressed that Ukrainian kulaks were not only economically suspect but also identified as nationalistic, and that Soviets used the famine to destroy Ukrainian nationalism. ${ }^{34}$

Helen Fein wrote, "Deliberate famines were imposed as a means of genocide in the Soviet Ukraine in 1932-1933, the Warsaw Ghetto in 1941-1942, and in other Jewish concentrated areas during the Holocaust." ${ }^{35}$ Andrea Gratsiozi noted that the Holodomor was genocide, but it was qualitatively different from the Holocaust's genocide. ${ }^{36}$

David J. Scheffer writes the following about famine in Ukraine in the 1930s: "Following strong Ukrainian peasants' resistance to agricultural collectivization, Soviet authorities closed

"Ukraine Calls on Russia to Stop Trying to Discredit Holodomor," last modified September 26, 2008, http://www.khpg.org.ua/en/index.php?id=1222377444.

$31 \quad$ Statute of the International Court of Justice, 1945, Art. 38.

32 Raphael Lemkin, "Soviet Genocide in the Ukraine," The Holodomor Studies 1 (2009).

33 James E. Mace, “Soviet Man-Made Famine in Ukraine," in Century of Genocide: Eye Witness Accounts and Critical Views, ed. Samuel Totten et al. (1997); Alain Bezanson, Le Malheur du siècle: sur le communisme, le nazisme et l'unicité de la Shoah (Kyiv: Pulsary University Publisher, 2007), 12, 29, 114; Roman Serbyn, "The Ukrainian Famine of 1932-1933 as Genocide in the Light of the UN Convention of 1948," The Ukrainian Quarterly 62.2 (2006): 186-204. Robert Conquest, The Harvest of Sorrow: Soviet Collectivization and the Terror-Famine (New York; Oxford: Oxford University Press, 1986), 328. Helen Fein, "Discriminating Genocide from War Crimes: Vietnam and Afganistan Reexamined," Denver Journal of International Law \& Policy 22 (1993): 33.

36 Andrea Gratsiozi, "Do chytachiv ukrainskoho vydannia 'Lystiv z Kharkova," ["To the Readers of the Ukrainian Edition of Letters from Kharkiv,"] in Lysty z Kharkova. Holod v Ukrayini ta na Pivnichnomu Kavkaziv povidomlenniakh italiyskykh dyplomativ.1932-1933 roky (Kharkiv: Folio, 2007), 42-43. 
the Ukrainian border and prevented Ukrainians from migrating. An estimated 4.8 to 10 million peopled starved to death." 37

Rett R. Ludwikowski calls the famine in Ukraine a "forgotten holocaust,"38 as Stalin dumped millions of tons of wheat on the Western markets, while in Ukraine, men, women, and children were dying of starvation at a rate of 25,00o a day or seventeen people per minute. ${ }^{39}$

As Jonah Goldberg states, "under the Holodomor, Ukrainian culture was systematically erased by the Russian Soviets, who saw it as inferior or expendable." 40

Such a brief analyses of different legal documents on the events of the Holodomor from 1932-1933 in Ukraine suffice to qualify this grave crime as genocide against Ukrainians under international law.

\section{Legal Accountability for Crimes of Totalitarian Regimes in Europe}

The issue of legal accountability for crimes against humanity was raised for the first time in Nuremberg. The crimes included "murder, extermination, enslavement, deportation, and other inhumane acts committed against any civilian population, before or during the war; or persecutions on political, racial, or religious grounds in execution of or in connection with any crime within the jurisdiction of the Tribunal, whether or not in violation of the domestic law of the country where perpetrated." ${ }^{41}$ Both the International Criminal Tribunal for former Yugoslavia and International Criminal Tribunal for Rwanda have jurisdiction over crimes of genocide, war crimes and crimes against humanity committed on the territory of these states. The International Criminal Court founded by the 1998 Rome Statute has jurisdiction over these crimes and crime of aggression committed by citizens of states that have ratified the Rome Statute and on the territory of these states.

In Europe, issues pertaining to the legal accountability of former totalitarian regimes were brought forward again after the collapse of the Communist regimes in the region. Council of Europe Resolutions in 1996 and 2006 confirmed the duty of states to punish prior regimes for grave human rights violations. In its Resolution 1096 (1996), ${ }^{42}$ PACE stressed the need to ensure that the cause of justice is served and the guilty are punished. PACE also recommends that states prosecute individuals who committed criminal acts during the communist totalitarian regime

David J. Scheffer, “Toward a Modern Doctrine of Humanitarian Intervention," University of Toledo Law Review 23 (1992): 254.

38 Rett R. Ludwikowski, "Searching for a New Constitutional Model for East-Central Europe," Syracuse Journal of Inernational Law and Commerce 17 (1991): 109.

39 See: Conquest, The Harvest of Sorrow.

40 Jonah Goldberg, "The Genocide Loophole. Claims of the 'Greater Good' too Often Let Mass Murderers off the Hook," accessed June 17, 2013, http://articles.latimes.com/2008/apr/o8/opinion/oe-goldberg8.

41 Article 6 (c) of the Charter of the International Military Tribunal, accessed June 17, 2013, http://legal.un.org/ilc/documentation/english/a_cn4_5.pdf.

42 The Council of Europe Resolution 1096 (1996) on Measures to dismantle the heritage of former communist totalitarian systems. 
under the standard Criminal Code. If the Criminal Code provides for a statute of limitations, extending the limit is possible because the limit is procedural, not substantive one. However, retroactive criminal laws are impermissible. On the other hand, states may punish a person for an act or omission that was not then a criminal offense under national law but was criminal according to the general principles of law recognised by civilised nations. Moreover, when a person violates human rights, the claim of having acted under orders excludes neither illegality nor individual guilt.

Of course, those charged with a crime are entitled to due process, which includes notice of the charge and the right to be heard. In Resolution 1096, PACE welcomed the opening of secret service files for public examination in some former communist totalitarian countries. ${ }^{43}$ It stressed that lustration, introduced in several states to exclude persons from exercising governmental power, can be compatible with a democratic state under the rule of law if the persons excluded cannot be trusted to exercise power in compliance with democratic principles. As the Resolution noted, "The aim of lustration is not to punish people presumed guilty — this is the task of prosecutors using criminal law - but to protect the newly emerged democracy."44

While calling on the countries concerned to comply with the suggested principles, Resolution 1096 was silent on the crimes of the totalitarian communist regimes themselves. Ten years later, it was evident that the fall of the totalitarian communist regimes in Central and Eastern Europe had not been followed in every case by an international investigation of the crimes committed by those regimes. Moreover, the international community had not tried the perpetrators of these crimes, as was the case with the Nazi's crimes. Following a report on "The Need for International Condemnation of the Crimes of Totalitarian Communist Regimes," authored by Goran Lindblad, a member of the Swedish parliamentary delegation to the Council of Europe, PACE passed Resolution 1481 on 27 January 2006, which for the first time strongly condemned the crimes committed by totalitarian communist regimes. ${ }^{45}$

Resolution 1481 listed massive violations of human rights committed by totalitarian communist regimes. These violations include individual and collective assassinations and executions; deaths in concentration camps; starvation, deportations, torture, slave labor, and other forms of mass physical terror; persecution on ethnic and religious grounds; violations of the freedom of conscience, thought, expression, and freedom of the press; and a lack of political pluralism. PACE stressed that public awareness of crimes committed by totalitarian communist regimes is one of the preconditions for avoiding similar crimes in the future.

43 Ukraine followed its obligation under this Resolution. The book Rozsekrechena pamiat. Holodomor 1932-1933 rokiv v Ukrainiv dokumentakh HPU-NKVD [The Declassified Memory. The Holodomor of 1932-1933 in Ukraine in Documents of GPU-NKVD] (Kyiv: Stylos, 2007) disclosed materials from the State archive of the Security Service of Ukraine on the Holodomor of 1932-1933.

44 Resolution 1096 (1996) on Measures to dismantle the heritage of former communist totalitarian systems, Paragraph 11.

45 Council of Europe Resolution 1481 (2006) on Need for international condemnation of crimes of totalitarian communist regimes: Text adopted by the Parliamentary Assembly of the Council of Europe on January 25, 2006 (5 th Sitting), accessed May 5, 2013, http://assembly.coe.int/Mainf.asp?link=/Documents/AdoptedText/tao6/Eres1481.htm. 
More recent PACE Resolution 1723 (2010) on Commemorating the victims of the Great Famine [Holodomor] in the former USSR noted that in Ukraine, which suffered the most, the peasantry was particularly hard-hit by the Great Famine and that millions of individual farmers and their family members died of hunger following forced "collectivisation," a ban on departures from the affected areas, and the confiscation of grain and other food. ${ }^{46}$ The Resolution states that these tragic events are referred to as the Holodomor (that is, as a politically motivated famine), and that Ukrainian law recognizes the Holodomor as an act of genocide against Ukrainians. The Resolution strongly condemned the cruel policies pursued by the Stalinist regime, which resulted in the death of millions of innocent people, as a crime against humanity.

\section{Issues of Legal Accountability for Holodomor of 1932-1933 in Contemporary Ukraine}

Although in Ukraine the Holodomor of $193^{2-1933}$ is politically and legally recognized as a crime of genocide under the Genocide Convention, ${ }^{47}$ a court did not rule that it was a crime of genocide until 13 January 2010. As discussed above, on that date the Appeal Court of Kyiv ruled that certain leaders of the Communist Party of the Soviet Union and of the Communist Party of Ukraine organized the genocide to suppress the national liberation movement in Ukraine and to prevent the restoration and consolidation of an independent Ukrainian state.

However, even before that court decision, the question of legal responsibility for the crime of the Holodomor in Ukraine was presented by the then-pending draft Law "On Punishing for Public Denial of the Holodomor and the Holocaust." In January 2008, the Law Enforcement Legislative Support Committee [Komitet z pytan zakonodavchoho zabezpechennia pravookhoronnoi diialnosti] recommended the Verkhovna Rada of Ukraine to adopt, as a basis for further consideration, the Law "On Amendments to the Criminal and Criminal Procedural Codes of Ukraine (regarding the Liability for Public Denial of the Fact of the 1932-1933 Holodomor in Ukraine)."

The proposed amendment consisted of adding a new Article $442^{1}$ to the Criminal Code of Ukraine: "The public denial of the Holodomor of 1932-1933 in Ukraine as a genocide against the Ukrainian people, and the Holocaust as a genocide against the Jewish people." Specifically, this Article provided for "a penalty of 100 to 300 times the untaxed minimum income level, or a custodial sentence for up to two years, for the public denial of the fact of the 1932-1933 Holodomor in Ukraine as a genocide against the Ukrainian people, and the Holocaust as

46 Council of Europe Resolution 1723 (2010) on Commemorating the victims of the Great Famine (Holodomor) in the former USSR: Text adopted by the Parliamentary Assembly of the Council of Europe on April 28, 2010 (15th Sitting), accessed May 5, 2013, http://assembly.coe.int/mainf.asp?link=/documents/adoptedtext/ta1o/eres1723.htm.

47 Law of Ukraine "On the Holodomor of 1932-1933 in Ukraine," Article 1: "The Holodomor of 19321933 in Ukraine is genocide against the Ukrainian people"; Conclusion Regarding the juridical characterization of the Holodomor of 1932-1933 in Ukraine as the genocide of the Ukrainian people in relation to the definition formulated in the 1948 UN Convention on the Prevention and Punishment of the Crime of Genocide. 
a genocide against the Jewish people, and for the preparing and dissemination of materials containing such denial." These same actions, if undertaken by officials or on a repeated basis, would lead to an imprisonment of up to four years.

These offences, according to amendments to Article 112 of the then Criminal Procedural Code of Ukraine, ${ }^{48}$ would be subject to a pre-trial inquiry by the investigating bodies of the Security Service of Ukraine.

Some committee members objected to this amendment during the discussion of the draft Law. These objections notably included the absence of precedent elsewhere in the world for imposing criminal liability for public statements by citizens and doubts as to the extent of such liability, with the objectors considering it "rather strict."49

In response, the People's Deputy, Volodymyr Moisyk, upon presentation of this draft Law at the Committee Meeting, argued that it was compatible with the Ukrainian Constitution. As an example, he referred to the Article 34 of the Ukrainian Constitution, which provides that "[ $t]$ he exercising of these rights may be restricted by law for the sake of national security, and territorial integrity or public order, with the purpose of preventing disturbances or crimes."50 Therefore, argued V. Moisyk, the limitation of rights, such as freedom of speech, was justified for the sake of national security. He added that more than ten European countries impose criminal liability for the public denial of the Holocaust. With this in mind, Committee Members recommended the Ukrainian Parliament to adopt the Law "On Amendments to The Criminal and Criminal Procedural Codes of Ukraine (regarding the Liability for Public Denial of the fact of the 1932-1933 Holodomor in Ukraine)" at the first reading. ${ }^{51}$

Various scholars have opined on the need for a judicial determination on the Holodomor. While one group of scholars argues that the facts of the Holodomor have been established through the evidence from surviving victims, others state that it will only be possible to introduce legal responsibility for the denial of the Holodomor after the fact of the Holodomor has been determined by courts in legal cases.

Views differ on criminal responsibility for the Holodomor. Lawyers and theoreticians of law who rely exclusively on national legislation argue that the Criminal Code of Ukraine (Art. 5), the law on criminal responsibility that imposes penalties for criminal offences, has no retroactive force. In other words, the law in force at the time of the act determines whether the actor is criminally responsible. However, Ukraine has ratified the 1968 Convention on the NonApplicability of Statutory Limitations to War Crimes and Crimes Against Humanity ${ }^{2}$ and the 1974 European Convention on the Non-Applicability of Statutory Limitations to Crimes Against

48 It lost force on 19 November 2012. The New Criminal Procedural Code has not the same, but of the similar character Article 216.

49 "Verkhovna Rada of Ukraine," accessed August 7, 2014, http://iportal.rada.gov.ua/en/news/News/page/en/news/News/1242o.html.

$5^{\circ}$ "Verkhovna Rada of Ukraine."

$51 \quad$ "Verkhovna Rada of Ukraine."

$5^{2}$ Convention on the Non-Applicability of Statutory Limitations to War Crimes and Crimes Against Humanity, UN GAOR, 23rd Sess., Supp. U. N. Doc. A/721818 (1968), 40. 
Humanity and War Crimes. ${ }^{53}$ Because of this and because the Holodomor was genocide, the penal provisions defining the applicable statute of limitations that were in effect at the time that the crime was committed do not apply.

Scholars who rely on international law applicable in Ukraine under Articles 8 and 9 of the Constitution and under the Law "On International Treaties of Ukraine" argue that the Holodomor was genocide under international law. They add that because the prohibition against genocide is a peremptory norm (jus cogens) of common international law, no statute of limitations applies. Moreover, they assert that the norm of "no offence without law" is superseded in the case of the Holodomor by the norm "nothing shall prejudice the trial and punishment of any person for any act or omission which, at the time when it was committed, was criminal according to the general principles of law recognized by the community of nations. This law includes Article 15 of the International Covenant on Civil and Political Rights and Article 7 of the Convention for the Protection of Human Rights and Fundamental Freedoms.

Finally, the Appeal Court of Kyiv ascertained that leaders of the Communist Party of the Soviet Union and of the Communist Party of Ukraine Stalin, Molotov, Kaganovich, Postyshev, Kosior, Chubar, and Khataievich, deliberately organized genocide of the part of the Ukrainian national group. Their purpose was to suppress the national liberation movement in Ukraine and prevent the restoration and consolidation of an independent Ukrainian State, by creating conditions of life calculated to bring about its destruction through the Holodomor of 1932-1933 which resulted in the deaths of $3,941,000$ people. ${ }^{54}$

\section{Conclusion}

The events of the Holodomor of 1932-1933 in Ukraine were possible because the Soviet government realized that it would not be accountable for this crime and did everything to conceal the famine. The issue of accountability for the Holodomor was never raised by the Communist Party of the Soviet Union or by the Communist Party of Ukraine. If the government were to be accountable to the public through elections, free news reporting, and uncensored public criticism, then it would do its best to eradicate famine. ${ }^{55}$ As Amartya Sen argues, famine reflects an institutional breakdown in accountability and feedback mechanisms. ${ }^{56}$

After Khrushchev's report in 1956 revealing Stalin's crimes, the organizers of the Holodomor were still not held accountable. The International Commission of Inquiry found that the responsibility for the famine almost certainly lies with the authorities of the Soviet Union, more specifically those within the various echelons of Soviet society who carried out

53 European Convention on the Non-Applicability of Statutory Limitation to Crimes Against Humanity and War Crimes, January 25, 1974, Eur. T.S. 82 (1974).

Ruling [Postanova] of the Kyiv Court of Appeal in the criminal case opened by the Security Service of Ukraine on the fact of committing genocide against Ukrainians in 1932-1933, 2010. See: John Norton Moore, “Toward a New Paradigm: Enhanced Effectiveness in United Nations Peacekeeping, Collective Security, and War Avoidance," Virginia Journal of International Law 37 (1997): 831.

56 Amartya Sen, "Freedoms and Needs: An Argument for the Primacy of Political Rights," New Republic, February 10, 1994, 31-38. 
those measures that for ten months created a dire shortage of foodstuffs in Ukraine. However, whatever the role of these local authorities who enforced particular policies, the Commission's majority concluded that the primary responsibility rested with the central powers. Nevertheless, this decision failed to provoke a reaction by the USSR.

Only since 1991, following the independence of Ukraine did the issue of accountability for the Holodomor start to be raised. Accountability cannot nowadays be in the form of criminal prosecution - no one responsible for the Holodomor is alive to be prosecuted. The Appeal Court of Kyiv, having accused the leaders of the Communist Party of the USSR and Ukrainian SSR Stalin, Molotov, Kaganovich, Postyshev, Kosior, Chubar, and Khataievich in masterminding genocide of the part of Ukrainian national group, decided to close the criminal case due to their deaths.

Other forms of retribution remain possible, however. One important way is through formal apologies offered by governments to the victims. ${ }^{57}$ An example of this would be the public apology for the Irish potato famine of the nineteenth century issued by Tony Blair, Prime Minister of Great Britain. When Blair apologized, he did it as the representative of the current government of the United Kingdom and on the part of the governments that ruled in the nineteenth century. ${ }^{58}$

As the Communist Party of the USSR is now defunct, but the Communist Party of Ukraine exists and thrives, it would be logical to hold it accountable. Punishment for the Holodomor will help Ukraine cope with its totalitarian communist past and fulfill its obligations under the Genocide Convention and Parliamentary Assembly of the Council of Europe's Resolution 1481 "On the Need for International Condemnation of the Crimes of Totalitarian Communist Regimes." For the sake of developing a solid Ukrainian nation, it is imperative to follow the affirmative international legal obligation on states to investigate and to make prior regimes accountable for their grave human rights violations. The case of the Holodomor in Ukraine as genocide against the Ukrainian people is waiting to be pleaded in an international judicial body.

\section{Bibliography}

Bezanson, Alain. Lykho stolittia: pro komunizm, natsyzm ta unikalnist Holokostu [Le Malheur du siècle: sur le communisme, le nazisme et l'unicite de la Shoah]. Kyiv: Pulsary, 2007.

Conquest, Robert. The Harvest of Sorrow: Soviet Collectivization and the Terror-Famine. New York; Oxford: Oxford University Press, 1986.

Fein, Helen. "Discriminating Genocide from War Crimes:Vietnam and Afghanistan Reexamined." Denver J. Int'l L. \& Policy 22 (1993): 29.

Gratsiozi, Andrea, ed. Lysty z Kharkova. Holod v Ukraini ta na Pivnichnomu Kavkazi v povidomlenniakh italiyskykh dyplomativ 1932-1933 roky [Letters from Kharkiv. Famine in Ukraine and in the Northern Caucasus in Notifications from Italian Diplomats of 1932-1933]. Kharkiv: Folio, 2007.

57 Trudy Govier, “Wilhelm Verwoerd. Taking Wrongs Seriously: A Qualified Defence of Public Apologies," Saskatchewan Law Review 65 (2002): 139.

$5^{8}$ Govier, "Wilhelm Verwoer," 139. 
Gratsiozi, Andrea. "Do chytachiv ukrainskoho vydannia 'Lystiv z Kharkova." ["To the Readers of the Ukrainian Edition of Letters from Kharkiv."] In Lysty z Kharkova. Holod v Ukrayini ta na Pivnichnomu Kavkazi v povidomlenniakh italiyskykh dyplomativ1932-1933 roky, 15-52. Kharkiv: Folio, 2007.

Investigation of the Ukraine Famine 1932-1933. Report to Congress. Commission on the Ukraine Famine. Adopted by the Commission April 19, 1988. Submitted to Congress April 22, 1988. Washington: United States Government Printing Office, 1988.

“German Government Report on Vinnytsia 1944." In The Tragedy of Vinnytsia Materials on Stalin's Policy of Extermination in Ukraine during the Great Purge, 1936-1938, edited by Ihor Kamenetskyi, 91-235. Toronto; New York: Ukrainian Historical Association, 1989.

Govier, Trudy, and Wilhelm Verwoerd. "Taking Wrongs Seriously: A Qualified Defence of Public Apologies." Saskatchewan Law Review 65 (2002): 139-62.

Kondrashin, V., and D. Penner. Golod: 1932-1933 gody v sovietskoi derevnie (na materialakh Povolzhia, Dona i Kubani) [Famine of 1932-1933 in a Soviet Village: On the Materials of Volga Region, Don and Kuban]. Samara-Penza, 2002.

Kamenetsky, Ihor, ed. The Tragedy of Vinnytsia: Materials on Stalin's Policy of Extermination in Ukraine during the Great Purge, 1936-1938. Toronto; New York: Ukrainian Historical Association, 1989.

Lemkin, Raphael. "Soviet Genocide in the Ukraine." The Holodomor Studies 1 (2009): 3-8.

Ludwikowski, Rett R. "Searching for a New Constitutional Model for East-Central Europe." Syracuse J. Int'l L. and Commerce 17 (1991): 91-170.

Mace, James E. "Soviet Man-Made Famine in Ukraine." In Century of Genocide: Eyewitness Accounts and Critical Views, edited by Samuel Totten et al., 78-112. New York: Garland Publishing, 1997.

Mace, James. "The Voices of Suffering." Ukrainian World 3-12 (1993): 34.

Marochko, V. "Dyplomatiia zamovchuvannia: Stavlennia zakhidno-ievropeiskykh derzhav do Holodomoru 1932-1933 rr. v Ukrayini." ["The Failure to Mention Diplomacy: Attitude of the Western Europe States towards the Holodomor of 1932-1933 in Ukraine."] In Holodhenotsyd 1933 roku $v$ Ukraini: Istoryko-politolohichnyi analiz sotsialno-demohrafichnykh ta moralno-psykholohichnykh naslidkiv. Paper presented at the international scientific and theoretical conference, November 28, 1998. Kyiv; New-York: M. P. Kots Publisher, 1998.

Moore, John Norton. "Toward a New Paradigm: Enhanced Effectiveness in United Nations Peacekeeping, Collective Security, and War Avoidance." Virginia Journal of International Law 37 (1997): 811-9o.

My zvynuvachuiemo! Holodomor 1932-1933 rokiv - henotsyd ukrainskoho narodu [We Accuse! The 1932-1933 Holodomor as a Genocide of the Ukrainian People]. Kyiv: Ukrainskyi instytut natsionalmoi pamiati, 2007.

Rezie, Richard. "The Ukrainian Constitution: Interpretation of the Citizens' Rights Provisions." Case Western Reserve Journal of Intenational Law 31 (1999): 169-97.

Scheffer, David J. "Toward a Modern Doctrine of Humanitarian Intervention." University of Toledo Law Review 23 (1992): 253-93. 
Sen, Amartya. "Freedoms and Needs: An Argument for the Primacy of Political Rights." New Republic, January 10, 1994.

Serbyn, Roman. "The Ukrainian Famine of ${ }^{1932-1933}$ as Genocide in the Light of the UN Convention of 1948." The Ukrainian Quarterly 62.2 (2006): 186-204.

\section{(2)}

Myroslava Antonovych is the Head of the Centre for International Human Rights and an Associate Professor of the Law School at the National University of Kyiv-Mohyla Academy. She has graduated Faculty of Law of Lviv Ivan Franko National University (Lviv, Ukraine, 1995); has LLM from McGill University (Montreal, Canada, 1999); Candidate of Philology Degree from Kyiv Linguistic University (Kyiv, Ukraine, 1988) and Doctor of Law Degree from Ukrainian Free University (Munich, Germany, 2008). In 2010-2014 Myroslava Antonovych was a judge ad hoc from Ukraine at the European Court of Human Rights. She is the author of more than 100 publications in International Law, International Human Rights and Genocide Studies. 